\title{
Editorial
}

\section{The local touch}

In public health nutrition, many of the most effective measures need to be implemented at the local level. Even the best policies or actions will fail if the local level is not prepared, for example with knowledge, skills, structure and systems, that allow pertinent implementation. In the latest policies and action plans at European and national levels, local environmental action is often emphasized. These types of action can involve for example city planning, transportation planning, school-yard size and design, local safety and lighting. The local level has also been important from the more traditional public health nutrition perspective, where focus has often been on access to good food, food stores, restaurants, school meals and a meal service or delivery system for elderly.

\section{Residential environments and their importance for health}

A favourite paper of the Editor-in-Chief of this journal is the one by Ana Diez-Roux, published in $2003^{(1)}$. This paper discusses the importance of residential environments from a cardiovascular risk perspective, providing a schematic overview of factors of importance, from physical environment to social. The presence of safe roads for biking and walking, nice areas for outside play and city planning on the whole in relation to where food stores are located are important factors. Having a good local social network is also of immense importance for health and this can be improved by the way a local community is set up and functioning. We need to be reminded of how public health is so closely interlinked to what our home environment looks like. The schematic outline in Dr DiezRoux's paper ${ }^{(1)}$ is especially well suited for starting up a discussion on the local angle of public health nutrition.

The time has come to dig out the old term 'community nutrition' and evaluate what we have learnt about local action since the 1980s, when community nutrition was in fashion.

\section{The Ottawa Charter}

The good old Ottawa Charter for Health Promotion, first published in $1986^{(2)}$, lays out a number of factors that are prerequisites for health, including peace, shelter, education, food, income, a stable ecosystem, sustainable resources, social justice and equity. It also defines what health promotion action actually means, and defines the following parts: building a healthy public policy; creating supportive environments; strengthening community actions; developing personal skills; reorienting health services; and moving into the future. This definition places much of the responsibility for public health in local hands. In several countries, the responsibility for public health action is increasingly being transferred to the local community and this puts new demands on local decision makers and public servants.

The Ottawa Charter can be used as a framework for building healthy communities, as well as healthy nations and a healthy world. Healthy public policy means considering health in the development of all policies at every level, and installing a public health board at the local level to make sure that relevant information, workforce and capacity are available and that the process is kept on track.

\section{Agenda 21}

Most of us remember Agenda $21^{(3)}$ and the environmental development that was inspired by the UN Conference on Environment and Development in Rio de Janeiro in 1992, which actually led to local committees being formed in communities in a large number of countries. This example teaches us that local action can happen on a grand scale, the problem is keeping it sustained. Local action cannot run without fuel like a perpetual motion machine. There is a need for constant inspiration, re-evaluation, updating, workforce development, supervision and political support, the latter independent of party politics, in order to keep it moving.

\section{The CDC approach CHANGE}

The Centers for Disease Control and Development (CDC) launched a new approach last year, Community Health Assessment aNd Group Evaluation (CHANGE) - Building a Foundation of Knowledge to Prioritize Community Needs - An Action Guide ${ }^{(4)}$, as part of its Healthy Communities Program. This very nice tool can be used in most communities - sometimes in partnership with local universities or other stakeholders - in order to develop a local action plan building on local needs.

\section{In this issue}

Due to the current heartfelt need for examples of local research and action, the editors have identified a series of 
locally based papers for this issue of Public Health Nutrition. You can read about local monitoring, local interventions and local food store environments, workplace interventions and other useful topics ${ }^{(5-17)}$. We hope that you will enjoy the local reading while sitting in your local armchair, eating your local apple, and be further inspired to local action and global publishing.

Agneta Yngve

Editor-in-Chief

Marilyn Tseng

Irja Haapala

Geraldine McNeill

Allison Hodge

Deputy Editors

\section{References}

1. Diez Roux AV (2003) Residential environments and cardiovascular risk. J Urban Health 80, 569-589.

2. World Health Organization (1986) Ottawa Charter for Health Promotion. Can J Public Health 77, 425-430.

3. UN Department of Economic and Social Affairs, Division for Sustainable Development (2009) Agenda 21. http:// www.un.org/esa/dsd/agenda21/ (accessed April 2011).

4. Centers for Disease Control and Development (2010) CDC's Healthy Communities Program. Community Health Assessment aNd Group Evaluation (CHANGE): Action Guide and Tool Downloads. http://www.cdc.gov/healthycommunities program/tools/change/downloads.htm (accessed April 2011).

5. Adams J, Ganiti E \& White M (2011) Socio-economic differences in outdoor food advertising in a city in northern England. Public Health Nutr 14, 945-950.

6. Corsi DJ, Chow CK, Lear S et al. (2011) Shared environments: a multilevel analysis of community context and child nutritional status in Bangladesh. Public Health Nutr 14, 951-959.

7. Tester JM, Yen IH, Pallis LC et al. (2011) Healthy food availability and participation in WIC (Special Supplemental
Nutrition Program for Women, Infants, and Children) programme in food stores around lower- and higher-income elementary schools. Public Health Nutr 14, 960-964.

8. Lassen AD, Thorsen AV, Sommer HM et al. (2011) Improving the diet of employees at blue-collar worksites: results from the 'Food at Work' intervention study. Public Health Nutr 14, 965-974.

9. Bandoni DH, Sarno F \& Bandoni PCJ (2011) Impact of intervention on the availability and consumption of fruits and vegetables in workplace. Public Health Nutr 14, 975-981.

10. Carter OBJ, Pollard CM, Atkins JFP et al. (2011) 'We're not told why - we're just told': qualitative reflections about the Western Australian Go for $2 \& 5^{\circledR}$ fruit and vegetable campaign. Public Health Nutr 14, 982-988.

11. Williams E \& Harris N (2011) Understanding the nutrition information needs of migrant communities: the needs of African and Pacific Islander communities of Logan, Queensland. Public Health Nutr 14, 989-994.

12. ter Bogt NCW, Milder IEJ, Bemelmans WJE et al. (2011) Changes in lifestyle habits after counselling by nurse practitioners: 1-year results of the Groningen Overweight and Lifestyle study. Public Health Nutr 14, 995-1000.

13. Stark Casagrande S, Franco M, Gittelsohn J et al. (2011) Healthy food availability and the association with BMI in Baltimore, Maryland. Public Health Nutr 14, 1001-1007.

14. Bristow K, Capewell S, Abba K et al. (2011) Healthy eating in early years settings: a review of current national to local guidance for North West England. Public Health Nutr 14, 1008-1016.

15. Burns C, Bentley R, Thornton L et al. (2011) Reduced food access due to a lack of money, inability to lift and lack of access to a car for food-shopping: a multilevel study in Melbourne, Victoria. Public Health Nutr 14, 1017-1023.

16. Andreyeva T, Middleton AE, Long MW et al. (2011) Food retailer practices, attitudes and beliefs about the supply of healthy foods. Public Health Nutr 14, 1024-1031.

17. Gustafson AA, Sharkey J, Samuel-Hodge CD et al. (2011) Perceived and objective measures of the food store environment and the association with weight and diet among low-income women in North Carolina. Public Health Nutr 14, 1032-1038. 